matters relating to analyses performed by the various customs laboratories of the Indian ports. He was allowed to hold the post of special chemical adviser to the Finance Department of the Government of India in addition to his duties as a professor in the Government College and the University. This was a great strain, but he never grudged the extra burden placed on him. The work in connexion with the Customs Laboratory was not light. I deputized for him for two periods when he was on leave and $I$ can affirm that this work was quite a full-time job. Ultimately his suggestion to have a Central Customs Laboratory at Delhi was adopted, and he finally migrated from Lahore in 1939 as the head of this new Laboratory.

During his tenure as professor in the University of the Panjab, Dunnicliff published a large volume of work in collaboration with his students, which earned for the Panjab University a reputation as an active centre of research work. Many of his pupils now occupy important positions both in India and Pakistan. They are all grateful for the helping hand he lent whenever they met difficulties. His migration to Delhi helped in putting the Central Revenues Chemical Service on a firm footing. During the Second World War I was again associated with him in war work. Owing to the large demand for morphine and codeine, the production at the Ghazipur Opium Factory had to be re-organized. He also designed the present morphine extraction plant at Ghazipur. $\mathrm{He}$ had a flair for designing plant and equipment. On his retirement from the Central Board of Revenues Laboratories, he joined the Department of Transport, New Delhi, where he had to design portable producer gas plants for use in lorries and motor-cars in order to minimize the use of petrol.

Dunnicliff presided over the Chemistry Section of the Indian Science Congress in 1934. He was on the Indian Committee of the Royal Institute of Chemistry, and he and the late Prof. Gilbert Fowler did much for the Institute in India.

Dunnicliff was a good singer, and many a pleasant evening was spent by his friends at his home; he was also a proficient amateur actor, and during the summer season he produced many plays at Simla.

Dunnicliff will always be remembered in India as a good Englishman who gave it more than he received from it. Those who knew him recognized him as a giver and not a taker. He lived in India at a critical period of her history. His contribution to the growth of science in India was by no means negligible.

He leaves behind a devoted wife, to whom our sympathy is offered.

J. N. RAY

\section{Dr. S. L. Smith, C.B.E.}

By the death of Dr. S. L. Smith on October 27, engineering and in particular shipbuilding research in Britain have lost a prominent figure. Those who had the privilege of working with him will remember him as the most kindly and approachable of colleagues.

Stanley Livingston Smith was born in 1889 and received his technical education at the City and Guilds Engineering College, South Kensington, where he graduated as B.Sc. (London) and Associate of the City and Guilds Institute in 1909. A period of practical training at the Thames Ironworks, Shipbuilding and Engineering Co., Ltd., was followed by an engineering inspectorship with the Crown Agents for the Colonies. After a varied career during the First World War, including secret work for the Royal Society war committee and service as an engineering officer in the marine training section of the R.A.F., he returned to the City and Guilds College under Prof. W. E. Dalby. Awarded the degrees of M.Sc. in 1921 and D.Sc.(Eng.) in 1923 for his work on elastic hysteresis in steels, he was appointed assistant professor in 1926 and reader in mechanical engineering five years later. He represented the Imperial College of Science and Technology on the Surrey County Council and was appointed chief engineering inspector of technical institutions.

Just before the outbreak of war in 1939, he was appointed superintendent of the Engineering Department of the National Physical Laboratory. During the War he was responsible for the very varied warwork of that Department; to mention only three items, he was particularly concerned with the development of apparatus for rendering unexploded bombs harmless, gun design (he was a member of the Gun Design Committee), and (with the late Dr. G. A. Hankins) the building for external ballistic work of an 11-in. square supersonic wind tunnel, which until late in the War was the only supersonic tunnel of reasonable size available to the United Nations.

Despite these preoccupations, Smith found time for probably his most notable personal research, producing with Dr. W. A. Wood four papers on the applica. tion of X-ray methods to the study of the deformation and fracture of metals. It is, however, as an administrator of scientific research that he will be best remembered. In 1944, he became the first director of research of the British Shipbuilding Research Association, a post which he still held at his death. Under his leadership the Association has become the central research organization in Britain for the shipbuilding, ship-repairing and marine engineering industry. $\mathrm{He}$ organized the work of the Association in an unusual way; no laboratory was set up, but a wide variety of research contracts was placed with universities, other research institutions and industrial firms. Among many papers by Dr. Smith covering this work may be mentioned his Thomas Lowe Gray Lecture to the Institution of Mechanical Engineers in 1952 on ship research, that on the resistance experiments with the old Clyde steamer Lucy Ashton, modified for jet propulsion to avoid propeller drag, and recent papers on nuclear propulsion.

Smith was made C.B.E. in 1951. He had been a vice-president of the Institutions of Mechanical Engineers and of Naval Architects, and a member of many technical committees on marine (including nuclear) propulsion, structural steel, corrosion and other subjects, as well as of committees of other research institutions.

D. G. Sopwith

\section{Prof. H. J. Logie}

Prof. H. J. Logre died on November 8 at the age of thirty-nine. His untimely death came at a period when his research had become very productive, and has been a shock and a great loss to all his colleagues and friends. He received his early education at Benoni High School, went to the University of the Witwatersrand as a student in 1936 and graduated bachelor of science in 1938 with firsts in both mathematics and physics. In 1939 he was awarded first-class honours in physics, and in 